\title{
Comparison of Sublingual and Nasal Applications of Dexmedetomidine Premedication in Pediatric Patients
}

\author{
Çocuk Hastalar için Sublingual ve Nazal Deksmedetomidinin Premedikasyonun \\ Karşılaştırılması
}

(D) Leyla Kılınç, (D) Ayşe Hancı, (D) Hacer Şebnem Türk

University of Health Sciences Șișli Hamidiye Etfal Training and Research Hospital, Clinic of Anesthesiology and Reanimation, Istanbul, Turkey

\begin{abstract}
Introduction: Alpha-2 adrenergic agonists are used for premedication in the pediatric population to reduce separation anxiety and achieve smooth induction. The clinical effects of clonidine are similar in both oral and nasal routes. However, oral dexmedetomidine is not preferred because of its poor bioavailability. The objective of this study was to retrospectively evaluate the effects of nasal and sublingual dexmedetomidine premedication in children.

Methods: Sixty-seven patients aged between 2-6 years who underwent elective surgery and received sublingual $2-\mu \mathrm{g} \mathrm{kg}^{-1}$ or intranasal $2-\mu \mathrm{g} \mathrm{kg}^{-1}$ dexmedetomidine premedication one hour before induction of anesthesia were retrospectively evaluated. Heart rate, peripheral oxygen saturation and anxiety scores of patients were compared in 10-minute intervals starting before premedication and up to the operating room. Drug acceptance, parental separation and facemask acceptance were also compared.
\end{abstract}

Results: There was no significant difference between the two groups in terms of demographic characteristics. There was no significant difference in terms of hemodynamic data, including heart rate, respiratory rate and $\mathrm{SpO2}$. After sixty minutes of premedication, anxiolysis, mask acceptance and parental separation were comparable in two groups. The median sedation level of intranasal group was significantly higher than sublingual group 60 minutes after drug administration [3 (33 ) vs $3(1-3)$, respectively $p=0.006]$. However, the number of children with satisfactory sedation levels was similar in both groups one hour after premedication (Sublingual group $=97 \%$ vs Intranasal group $=100 \%$ ).

Conclusion: The clinical effects of intranasal and sublingual dexmedetomidine were similar. Level of sedation by sublingual route was less than intranasal route, because a significant proportion of the drug was ingested by children. It may be preferred for premedication in preschool children by intranasal route or at higher doses by sublingual route.

Keywords: Premedication, children, dexmedetomidine, sublingual, nasal
ÖZ

Amaç: Alfa-2 adrenerjik agonistler, pediyatrik popülasyonda premedikasyon için ayırma anksiyetesini azaltmak ve kalıcı indüksiyonu sağlamak için kullanılır. Klonidinin klinik etkileri oral ve nazal yolla benzerdir. Ancak, oral deksmedetomidin, zayıf biyoyararlanımı nedeniyle tercih edilmez. Bu çalışmanın amacı çocuklarda nazal ve sublingual deksmedetomidinin premedikasyon etkilerini retrospektif olarak değerlendirmektir.

Yöntemler: İki-altı yaş arasında elektif cerrahi uygulanan ve anestezi indüksiyonundan 1 saat önce premedikasyon amaciyla sublingual yolla $2 \mu \mathrm{g} / \mathrm{kg}^{-1}$ veya nazal yolla $2 \mu \mathrm{g} /$ $\mathrm{kg}^{-1}$ deksmedetomidin uygulanan 67 hasta retrospektif olarak incelendi. Hastaların kalp atım hızı, periferik oksijen satürasyonu, anksiyete skorları, premedikasyon öncesi ve ameliyathaneye kadar 10 dakikalık aralıklarla karşılaştırıldı. ilaç kabulü, ebeveyn ayrımı ve yüz maskesi kabulü de karşılaștırıldı.

Bulgular: Her iki grup arasında hastaların demografik özelliklerinde anlamlı bir fark yoktu. Her iki gruptada hemodinamik veriler arasında kalp hızı, solunum hızı ve $\mathrm{SpO}_{2}$ açısından anlamlı fark yoktu. Altmış dakikalık premedikasyon anksiyolizinden sonra, maske kabulü ve ebeveyn ayrımı iki grupta karşılaştırılabilirdi. Grup N'nin ortanca sedasyon seviyesi, ilaç verilmesinden 60 dakika sonra grup S'den anlamlı olarak yüksekti [3 (3-3) ve 3 (1-3), sırasıyla $p=0,006$. Bununla birlikte, tatmin edici düzeyde sedasyon seviyesi olan çocuk sayısı, premedikasyondan 1 saat sonra her iki grupta da benzerdi (grup $\mathrm{S}=\% 97$ ve grup $\mathrm{N}=\% 100$ ).

Sonuç: Deksmedetomidinin klinik etkileri intranazal ve sublingual yolla benzerdi. Sublingual yolla sedasyon seviyesi, çocuklar tarafından yutulmasından dolayı intranazal yoldan daha düşüktü. Okul öncesi çocuklarda intranazal yolla veya daha yüksek dozlarda sublingual yolla premedikasyon tercih edilebilir.

Anahtar Kelimeler: Premedikasyon, çocuklar, deksmedetomidin, sublingual, nazal 


\section{Introduction}

A satisfactory premedication provides a comfortable induction of general anesthesia with minimal hemodynamic changes and reduces emotional trauma in children before surgery. Because of children showing a psychological response to a needle, a non-invasive route has to be preferred for procedural sedation and anesthetic premedication. Oral or rectal administration of druges for sedation is not suitable because of difficult titration and because they may prolong the onset of sedation. Intranasal and sublingual administration may be preferred as they are painless, easy to use and less first pass metabolism.

Alpha-2 adrenergic agonists provide sedation with comfortable parental separation and alter conditions for induction of general anesthesia while conserving airway reflexes. Dexmedetomidine (DEX) is a more selective $\alpha 2$-agonist drug with shorter half-life. It shows sedative, analgesic, anxiolytic, and anesthetic effects by reducing arterial blood pressure and heart rate. DEX is tasteless, odorless and painless drug (1-3). DEX premedication provides sufficient premedication for general and regional anesthesia through buccal and intranasal route (4-6).

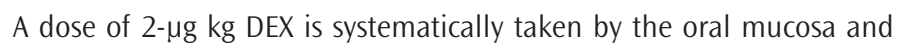
its buccal bioavailability is as high as $82 \%(73-92 \%)$ in adults (7). The absolute bioavailability of DEX was 65\% (35-93\%) following intranasal administration in adults (8). To the best of our knowledge, there is no study considering nasal and sublingual administration of DEX for premedication in children.

This study aimed to retrospectively evaluate sedative, respiratory and hemodynamic effects of sublingual and nasal DEX premedication in children.

\section{Methods}

The institutional Medical Ethic Committee of Şşli Hamidiye Etfal Research and Training Hospital approval was received (SEEAH, $980,17.04 .2018)$. Oral and written consents were obtained from the parents of the participants, the files of 67 children aged 2-6 years who underwent minor elective surgical procedures such as circumcision, inguinal hernia and tonsillectomy/adenoidectomy between October 2017 and April 2011 were retrospectively reviewed. Exclusion criteria were as follows: Mental retardation, autism, using analgesics and anticonvulsants during the peroperative period, and cerebral palsy.

Patients who received $2 \mu \mathrm{gg} \mathrm{kg}^{-1}$ DEX (Precedex ${ }^{\circledR}, 100 \mu \mathrm{g} / \mathrm{mL}$, Abbott Laboratories, North Chicago, IL, USA) premedication one hour prior to induction of anesthesia through sublingual route were identified as group $S(n=33)$ and intranasal route as group $N(n=34)$. The response of the child to drug administration was recorded using two-point scale (1= Poor, crying, $2=$ Good, not crying). Heart rate (HR), respiratory rate $(\mathrm{RR})$ and peripheral oxygen saturation $\left(\mathrm{SpO}_{2}\right)$ were recorded at 10 -minute intervals before (baseline) and after premedication. Level of sedation was recorded according to a three-point scale (1= Awake, $2=$ Drowsy, $3=$ Asleep). A 4-point scale was applied for preoperative anxiety (1= Crying, very anxious, $2=$ Anxious, not crying, $3=$ Calm, but not cooperative, $4=$ Calm, cooperative or sleep). Sedation score 2 or 3 and anxiety score 3 or 4 were considered as satisfactory response. Preoperative sedation and anxiety scores were recorded at 10-minute intervals until shifting to the operating room. Parental separation scores were assessed using three-point scale ( $1=$ Poor, anxious and combative, $2=$ Good, anxious but easily reassured, $3=$ Excellent, sleepy and calm). Parents were not allowed to accompany the child during induction of anesthesia. Mask acceptance was evaluated by a 4-point scale: 1= Poor (combative, crying), 2= Fear (moderate fear of the mask), 3= Good (cooperative with reassurance, $4=$ Excellent (calm, cooperative or sleep). The parents were admitted 5-10 minute after the children arrived to post anesthesia care unit and parents were interviewed regarding their satisfaction related to premedication before patients discharge from post-anesthesia care unit ( $1=$ Not satisfied, $2=$ Good, satisfied, $3=$ Excellent). All evaluation scores were adopted from published studies investigating premedication in children (9-11).

The adverse effects including respiratory depression ( $R R<12 / \mathrm{min}$ ), desaturation ( $\mathrm{SpO}_{2}<90 \%$ for 15 seconds) and bradycardia ( $\mathrm{HR}<60$ beat/ $\mathrm{min}$ ) were recorded from anesthesia forms.

\section{Statistical Analysis}

The data are presented as mean values with standard deviations, medians with range, or as a proportion with a 95\% confidence interval. Student's t-test was used to compare normally distributed continuous variables between the two groups and the nonparametric MannWhitney $\mathrm{U}$ test was used for the sedation scores, anxiety scores, parental separation and mask acceptance scores. Categorical data were analyzed by chi-square test or Fisher's exact test. A p value $<0.05$ was considered to be statistically significant. A power analysis indicated that a simple size of 28 was sufficient to detect a significant statistical difference with $\alpha=0.05$ and power of $80 \%$ in satisfactory sedation scores at parental separation between the two groups. We decided to study 67 patients to account for possible dropouts.

\section{Results}

Sixty-seven preschool-age children were included in this study, namely 34 children in group N and 33 children in group S. Demographic data were similar in both groups (Table 1).

There were no significant differences between the two groups in terms of $\mathrm{HR}$ and $\mathrm{RR}$ before and 60 minutes after premedication. $\mathrm{SPO}_{2}$ was comparable in both groups at all time points. No respiratory depression and bradycardia were observed in both groups (Table 2).

Drug acceptance by nasal and sublingual routes was comparable. Mean onset time for sedation was statistically shorter in group $\mathrm{N}$, but mean onset time for anxiolysis was similar between the two groups (Table 3).

Anxiolysis and mask acceptance after 60 minutes of premedication were similar in both groups. The sedation and parental separation scores of group $N$ were significantly better than group $S 60$ minutes after drug administration (Table 4).

Number of patients with sufficient sedation scores for parental separation, mask tolerance at induction of anesthesia and at 60 minutes after premedication were comparable in both groups (Table 5). Although satisfactory sedation scores at the $60^{\text {th }}$ minutes after receiving DEX were similar in both groups, sedation scores of the patients in 
group $\mathrm{N}$ were significantly higher than that of group $\mathrm{S}(\mathrm{p}<0.001)$. The reaction of children to parental seperation 60 minutes after receiving premedication was found to be excellent in 15 children (44\%) in group $\mathrm{N}$ compared to six children (18\%) in group S. The induction of general anesthesia was good or excellent in 22 children (65\%) in group N compared to 19 children (57\%) in group S. Number of patients with unsatisfactory parental seperation in group $S$ was statistically higher than that in group N. Six children (\%17) resisted intranasal medication and three children (9\%) resisted sublingual medication.

Table 1. Demographic data

\begin{tabular}{|l|l|l|l|}
\hline & Group S $(\mathbf{n}=33)$ & Group N $(\mathbf{n}=34)$ & $\mathbf{p}$ \\
\hline Age (year) & $4 \pm 1.57$ & $3.5 \pm 1.59$ & 0.17 \\
\hline Weight $(\mathrm{kg})$ & $16.51 \pm 3.93$ & $15.05 \pm 3.44$ & 0.53 \\
\hline Gender (M/F) & $25 / 8$ & $27 / 7$ & 0.46 \\
\hline M: male, F: female & & & \\
\hline
\end{tabular}

\section{Discussion}

In this retrospective study, we evaluated sedative, hemodynamic and respiratory effects of sublingual or intranasal DEX admininistration for premedication in preschool children. Two $\mu \mathrm{g} \mathrm{kg}^{-1}$ intranasal and sublingual DEX had comparable effects without affecting hemodynamic and respiratory parameters.

Preoperative sedation reduces separation anxiety and provide mask acceptance in the pediatric population. Because of psychological response to a needle, non-invasive approaches should be preferred for sedation in children. Intranasal and sublingual application of sedative drugs is painless, easy to use and bypasses first past metabolismimproving bioavailability over oral and rectal doses.

DEX is a selective $\alpha 2$-agonist drug with a short duration of activity. It was shown that the onset of sedation occurred at 45 minutes in healthy volunteers (12) and at 25 minutes in children (13) following intranasal

Table 2. Respiratory rate (RR), heart rate (HR), peripheral oxgen saturation $\left(\mathrm{SpO}_{2}\right)$ of groups

\begin{tabular}{|c|c|c|c|c|c|}
\hline & \multicolumn{2}{|l|}{ Group $S(n=33)$} & \multicolumn{2}{|c|}{ Group N (n=34) } & \multirow[t]{2}{*}{ p } \\
\hline & Baseline & $60^{\text {th }}$ minute & Baseline & $60^{\text {th }}$ minute & \\
\hline HR (beat/min) & $114.78 \pm 12.38$ & $100.75 \pm 10.22$ & $113.26 \pm 12.4$ & $98.67 \pm 11.19$ & 0.06 \\
\hline RR (rate/min) & $23.60 \pm 2.34$ & $21.15 \pm 1.93$ & $23.88 \pm 4.63$ & $19.11 \pm 3.13$ & 0.051 \\
\hline $\mathrm{SpO}_{2}$ & $99.42 \pm 0.57$ & $98.64 \pm 0.12$ & $99.23 \pm 0.58$ & $98.96 \pm 0.44$ & 0.12 \\
\hline
\end{tabular}

Table 3. Mean onset time for sedation and anxiolysis

\begin{tabular}{|l|l|l|l|}
\hline & Group $\mathbf{S}(\mathbf{n}=\mathbf{3 3})$ & Group $\mathbf{N}(\mathbf{n}=\mathbf{3 4})$ & \multicolumn{1}{|c|}{$\mathbf{p}$} \\
\hline Mean onset time for sedation (minutes) & $24.24 \pm 12.5$ & $18.23 \pm 11.13$ & 0.0417 \\
\hline Mean onset time for anxiolysis (minutes) & $29.69 \pm 11.03$ & $25.0 \pm 6.15$ & 0.1140 \\
\hline
\end{tabular}

Table 4. Sedation, anxiety, parental separation, mask acceptance scores 1 hour after premedication

\begin{tabular}{|l|l|l|l|}
\hline & Group $\mathbf{S}(\mathbf{n}=\mathbf{3 3})$ & Group $\mathbf{N}(\mathbf{n}=\mathbf{3 4})$ & $\mathbf{p}$ \\
\hline Sedation & $3(1-3)$ & $3(3-3)^{* *}$ & 0.0086 \\
\hline Anxiety & $4(1-4)$ & $4(3-4)$ & 0.1363 \\
\hline Parental separation & $2(1-3)$ & $2(2-3)^{* *}$ & 0.0321 \\
\hline Mask acceptance & $3(1-4)$ & $3(1-4)$ & 0.7354 \\
\hline
\end{tabular}

Data are presented as median (interquartile range), ${ }^{* *} p<0.001,{ }^{*} p<0.05$

Table 5. Anxiety and sedation scores at $60^{\text {th }}$ minute, sedation score at parental separation, mask tolerance at induction and parent satisfaction

\begin{tabular}{|l|l|l|l|}
\hline & $\begin{array}{l}\text { Group S (n=33) } \\
\mathbf{n}(\%)\end{array}$ & $\begin{array}{l}\text { Group N (n=34) } \\
\mathbf{n}(\%)\end{array}$ & $\mathbf{p}$ \\
\hline Satisfactory sedation score at parental separation & $32(97 \%)$ & $34(100 \%)$ & 0.4925 \\
\hline Satisfactory parental separation & $26(78 \%)$ & $30(88 \%)$ & 0.3405 \\
\hline Satisfactory anxiety score & $30(\% 90)$ & $34(100 \%)$ & 0.1139 \\
\hline Satisfactory mask tolerance at induction & $19(57 \%)$ & $22(65 \%)$ & 0.6205 \\
\hline Unsatisfactory parent & $14(43 \%)$ & $6(18 \%)^{*}$ & 0.0154 \\
\hline Sedation score & & & 0.0001 \\
\hline Asleep & $20(61 \%) * *$ & 0.0001 \\
\hline Drowsy & $12(36 \%) * *$ & 0.426 \\
\hline Awake & $1(3 \%)$ & $0(0 \%)$ & $0(0 \%)$ \\
\hline$* p<0.05, * * p<0.001$ & & & \\
\hline
\end{tabular}


DEX application. The absolute bioavailability of intranasal DEX was found to be $65 \%$ (35-93\%) and onset was more rapid after intravenous administration in healthy volunteers (8). Anttila et al. (7) reported that buccal DEX showed clinical sedative effects that correlated well with plasma level and that buccal bioavailability was as high as $82 \%$.

In our study, $100 \%$ of children in group $\mathrm{N}$ had satisfactory sedation scores for parental separation compared $97 \%$ of children in group S. Sedation and parental separation scores were better in group $\mathrm{N}$ at $60^{\text {th }}$ minute. Although buccal bioavailability is higher than intranasal bioavailability in healthy adults, our data were different in children. This may be due to drugs being swallowed by children involuntarily.

Yuen et al. (12) showed that approximately $75 \%$ and $92 \%$ of subjects attained a sedation level of modified Observer Assessment of Alertness/ Sedation scale of 3 or below after intranasal 1 and $1,5 \mu \mathrm{g} \mathrm{kg}^{-1} \mathrm{DEX}$, respectively, and that it produced sedation in 45-60 minutes (peak $=90$ 105 minutes). They also found that intranasal administration of $1 \mu \mathrm{g}$ $\mathrm{kg}^{-1}$ of DEX produced satisfactory sedation in $62 \%$ of children at the time of cannulation. The median time for onset of sedation was 25 (25-30) minutes and the median duration of sedation was 85 (55-100) minutes.

Schmidt et al. (6) compared preanesthetic effects of transmucosal DEX $1 \mu \mathrm{g} \mathrm{kg}{ }^{-1}$, oral midazolam $0.5 \mathrm{mg} \mathrm{kg}^{-1}$ and oral clonidine $4 \mu \mathrm{g} \mathrm{kg}^{-1}$ on postoperative pain and anxiety in children, and there was no difference between the groups in terms of sedation and response to separation scores, but pain scores, mean arterial pressure and HR were lower in DEX and clonidine groups than midazolam group.

Karaaslan et al. (5) demonstrated that buccal and intramuscular DEX

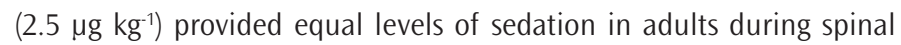
anesthesia. Sakurai et al. (4) applied DEX buccaly and found higher sedation scores, and suggested that 3-4 $\mu \mathrm{g} / \mathrm{kg}$ of buccal DEX might be less than the optimal dosage of preanesthetics.

Talon et al. (14) compared intranasal $2 \mu \mathrm{g} \mathrm{kg}{ }^{-1}$ DEX to oral cherry flavored midazolam syrup $0.5 \mathrm{mg} \mathrm{kg}$ for sedation in children, and DEX was found to be more effective and fast-acting, reliable, safe and relatively less traumatic.

Yuen et al. (15) compared two different doses of intranasal DEX (0.5 or 1 $\left.\mu \mathrm{g} \mathrm{kg}{ }^{-1}\right)$ to oral midazolam $\left(0.5 \mathrm{mg} \mathrm{kg}^{-1}\right)$. These authors found that both doses of DEX were superior to oral midazolam for sedation, and more adequate sedation at induction was achieved in patients receiving $1 \mu \mathrm{g}$ $\mathrm{kg}^{-1}$ dose.

Lami and Pereira (16) showed that 20 hospitalized patients aged 4 months-19 years with ASA physical status II-III received 2-3 $\mu \mathrm{g} \mathrm{kg}^{-1}$ DEX through the oral mucosa for elective computerized tomograpy. Twelve patients reached adequate sedation level after 10-45 minutes. Eight patients needed DEX supplementation by the same route or additional anesthesia techniques.

Zub (17) conducted a retrospective study to investigate the efficacy of buccal DEX as a procedural and anesthetic premedication. Thirteen children received buccal DEX at 1.0-4. $\mathrm{Mg} \mathrm{kg}^{-1}$ and effective sedation was achieved in 11 of 13 .

Yuen et al. (18) documented that $2 \mu \mathrm{g} \mathrm{kg}{ }^{-1}$ of intranasal DEX sedated satisfactorily $66 \%$ of patients at time of anesthetic induction. We found that mask tolerance in induction was $65 \%$ in patients in group $\mathrm{N}$ and $57 \%$ in patients in group S.

Cimen et al. (19) compared intranasal or buccal $1 \mu \mathrm{g} \mathrm{kg}^{-1}$ DEX for premedication in children and found that intranasal application was more effective.

Petroz et al. (20) compared a single intravenous dose of DEX (2, 4 and 6 $\left.\mu \mathrm{kg} \mathrm{h}^{-1}\right)$ in children and found that there was no association between DEX dose and depth of sedation in children. Roy et al. (21) showed that $2 \mu \mathrm{g} . \mathrm{kg}^{-1}$ intranasal DEX provided efficient sedation in children.

DEX may cause hemodynamic side effects such as hypotension and bradycardia, especially associated with dose infusion given over $<10$ $\min (6,20,22,23)$. DEX provided adequate sedation at $1 \mu \mathrm{g} \mathrm{kg}^{-1}$ loading and 0.5-0.7 infusion doses without affecting hemodynamics (24). Sakurai et al. (4) suggested that transmucosal buckle DEX (3-4 $\mathrm{g} \mathrm{kg}^{-1}$ ) provided sufficient and innocuous preoperative sedation of children. There were no cases with bradycardia (HR less than 60). In our study, HR did not decrease significantly after both administration routes.

\section{Conclusion}

This study demonstrated that nasal and sublingual DEX $\left(2 \mu \mathrm{g} \mathrm{kg}^{-1}\right)$ had similar effects as a preanesthetic medication in preschool children.

Ethics Committee Approval: The institutional Medical Ethic Committee of Şișli Hamidiye Etfal Research and Training Hospital approval was received (SEEAH, 980,17.04.2018).

Informed Consent: Oral and written consents were obtained.

Peer-review: Externally and internally peer-reviewed.

Authorship Contributions: Surgical and Medical Practices: L.K., A.H., H.S.T.; Concept: L.K., A.H., H.Ş.T.; Design: L.K., A.H., H.Ş.T.; Data Collection or Processing: L.K., A.H., H.S.T.; Analysis or Interpretation: L.K., A.H., H.Ş.T.; Literature Search: L.K., A.H., H.Ş.T.; Writing: L.K., A.H., H.Ş.T.

Conflict of Interest: No conflict of interest was declared by the authors.

Financial Disclosure: The authors declared that this study received no financial support.

Acknowledgements: The authors would like to thank all members of the pediatric surgery team for their support.

\section{References}

1. Bhana NL, Goa KL, McClellon KJ. Dexmedetomidine. Drugs 2000; 59: 263-8.

2. Phan $\mathrm{H}$, Nahata M. Clinical uses of dexmedetomidine in pediatric patients. Paediatr Drugs 2008; 10: 49-69.

3. Chrysostomou C, Schmitt CG. Dexmedetomidine: sedation, analgesia and beyond. Expert Opin Drug Metab Toxicol 2008; 4: 619-27.

4. Sakurai Y, Obata T, Odaka A, Terui K, Tamura M, Miyao H. Buccal administration of dexmedetomidine as a preanesthetic in children. J Anesthesia 2010; 24: 49-53.

5. Karaaslan D, Peker TT, Alaca A, Ozmen S, Kirdemir P, Yorgancigil H, et al. Comparison of buccal and intramuscular dexmedetomidine premedication for arthroscopic knee surgery. J Clin Anesth 2006; 18: 589-93.

6. Schmidt A, Valinetti EA, Bandeira D, Bertacchi MF, Simoes CM, Auler Joc. Effects of preanesthetic administration of midazolam, clonidine or 
dexmedetomidine on postoperative pain and anxiety in children. Pediatric Anesthesia 2007: 17: 667-74.

7. Anttila M, Penttila J, Helminen A, Vuorilehto L, Scheinin H. Bioavailability of dexmedetomidine after extravascular doses in healty subjects. $\mathrm{Br} J$ Clin Pharmacol 2003; 56: 691-3.

8. lirola T, Vilo S, Manner T, Aanta R, Lahtinen M, Scheinin M, et al. Bioavailability of dexmedetomidine after intranasal administration. Eur J Clin Pharmacol 2011; 67: 825-31.

9. Kogan A, Katz J, Efrat R, Eidelman LA., et al. Premedication with midazolam in young children : a comparison of four routes of administration. Paediatr Anaesth 2002; 12: 685-9.

10. Funk W, Jakob W, Riedl T, Taeger K. Oral preanaestheticmedication for children: double blind randomized study of a combination of midazolam and ketamine vs midazolam and ketamine alone. Br J Anaesth 2000; 84: 33540

11. Ghai B, Grandhe Rp, Kumar A, Chari P. Comparative evaluation of midazolam and ketamine with midazolam as oral premedication. Pediatr Anesth 2005; 15: 554-9.

12. Yuen VM, Irwin MG, Hui TW, Yuen Mk, Lee LH. A double-blind, crossover assessment of the sedative and analgesic effects of intranasal dexmedetomidine. Anesth Analg 2007; 105: 374-80.

13. Yuen VM, Hui TW, Irwin MG, Yao TJ, Wong GL, Yuen MK. Optimal timing for the administration of intranasal dexmedetomidine for premedication in children. Anesthesia 2010; 65: 922-9.

14. Talon Md, Woodson LC, Sherwood ER, Aarsland A, McRoe LBA, Benham TBSN. Intranasal dexmedetomidine premedication is comparable with midazolam in burn children undergoing reconstructive surgery. 2009; 30: 599-605.

15. Yuen VM, Hui TW, Irwin MG, Yuen MK. A comparison of intranasal dexmedetomidine and oral midazolam for premedication in pediatric anesthesia: a double-blinded randomized controlled trial. Anesth Analg 2008; 106: 1715-21.
16. Lami RO, Pereira ACP. Transmucosal dexmedetomidine for computed tomography sedation. Pediatric Anesth 2008; 18: 349-78.

17. Zub D. Preliminary experience with oral dexmedetomidine for procedural and anesthetic premedication. Paediatric Anaesthesia 2005; 15: 932-8.

18. Yuen VM, Hui TW, Irwin MG, Yao TJ, Chan L, Wong GL, et al. A randomized comparison of two intranasal dexmedetomidine doses of premedication in children. Anaesthesia 2012; 67: 1210-6.

19. Cimen ZS, Hanci A, Sivrikaya GU, Kilinc LT, Erol MK. Comparison of buccal and nasal dexmedetomidine premedication for pediatric patients. Pediatr Anesth 2013; 23: 134-8.

20. Petroz GC, Sikich N, James M, Van Dyk H, Shafer SL, Schily M, et al. A phase I, two-center study of the pharmacokinetics and pharmacodynamics of dexmedetomidine in children. Anesthesiology 2006; 105: 1098-110.

21. Roy S, Bhattacharya D, Biswas M, Pandit P, Ghosh S, Debnath AK, et al. Comparative study of nasal dexmedetomidine versus nasal midazolam as premedication in children undergoing elective surgical procedure under general anaesthesia. International Journal of Basic and Applied Medical Sciences 2012; 2: 68-73.

22. Venn RM, Bradshaw CJ, Spencer R, Brealey D, Caudwell E, Naughton C, et al. Preliminary UK experience of dexmedetomidine. A novel agent for postoperative sedation in the intensive care unit. Anaesthesia 1999; 54: 113642.

23. Munro HM, Tirotta CF, Felix DE, Lagueruela RG, Madril DR, Zahn EM, et al Initial experience with dexmedetomidine for diagnostic and interventional cardiac catheterization in children. Paediatr Anaesth 2007; 17: 109-12.

24. Koroglu A, Demirbilek S, Teksan H, Sagır O, But AK, Ersoy MO. Sedative, haemodynamic and respiratory effects of dexmedetomidine in children undergoing magnetic resonance imaging examination: preliminary results. Br J Anaesth 2005; 94: 821-24. 